\title{
Safety of newer biological insecticide spinetoram 12 SC to Cryptolaemus montrouzieri in the grapevine ecosystem of Tamil Nadu
}

A. SANJEEVI KUMAR*, N. MUTHUKRISHNAN, A. PAVVIYA, K. MARUTHUPANDI, V. AMSAGOWRI, G. ARULKUMAR, S. SEKAR AND M.P. BHARATH

Department of Agricultural Entomology, Tamil Nadu Agricultural University, COIMBATORE (T.N.) INDIA

\section{ARITCLE INFO}

Received : 01.02 .2016

Revised : 03.03 .2016

Accepted : 12.03 .2016

KEY WORDS :

Spinetoram, Grapevine, Cryptolaemus montrouzieri
*Corresponding author:

Email: sanjeeviento14@gmail.com

\begin{abstract}
A field experiment was conducted at farmers' field in Dindigul district, Tamil Nadu, India during the year August 2012 - December 2012 to study the effect of new biological insecticide spinetoram 12 SC to Cryptolaemus montrouzieri of grapevine mealy bug, Maconellicoccus hirsutus. Three foliar applications were carried out at an interval of fifteen days after nymphs and adults $C$. montrouzieri population reached economic threshold level. The result showed that the overall mean population of $C$. montrouzieri was found to be more in the untreated check followed by spinetoram $12 \mathrm{SC} 27 \mathrm{~g}$ a.i/ha in the first, second and third foliar application. The overall mean population of $C$. montrouzieri was high in the untreated check, followed by spinetoram 12 SC $30 \mathrm{~g}$ a.i/ ha over the other treatments.

How to view point the article : Kumar, A. Sanjeevi, Muthukrishnan, N., Pavviya, A., Maruthupandi, K., Amsagowri, V., Arulkumar, G., Sekar, S. and Bharath, M.P. (2016). Safety of newer biological insecticide spinetoram $12 \mathrm{SC}$ to Cryptolaemus montrouzieri in the grapevine ecosystem of Tamil Nadu Internat. J. Plant Protec., 9(1) : 230-232.
\end{abstract}

